\title{
The 36th International Technical Conference on Circuits/Systems, Computers and Communications
}

\author{
(ITC-CSCC 2021, 回路とシステム/コンピュータ及び通信に関する国際会議) \\ Grand Hyatt Jeju, Jeju-do, Republic of Korea（オンラインとのハイブリッド開催） \\ 2021 年 6 月 28 30日, https://itc-cscc2021.org/
}

今回で 36 回めとなるITC-CSCC は, 回路とシステム, コンピュータと通信に関する幅広い研究分野を網羅する学術 国際会議であり, 電子情報通信学会基礎・境界ソサイエ ティ, The Institute of Electronics and Information Engineers (IEIE), タイ The Electrical Engineering/ Electronics, Computer, Telecommunications and Information Association (ECTI) との共同主催により, 毎年, 6 月下旬から 7 月中旬の期間で開催されています. 本国際会議は, アジア地域における研究者の交流を活性化 し, 広く世界で活躍できる研究者を育成する目的で, 当初 は, 日本と韓国の若手研究者の合同研究会としてスタート し, 以後, タイを加えた 3 か国で開催地をローテーション しています.

今年の開催地は, 韓国の代表的なリゾート地である済州島 でしたが, 新型コロナウイルスの影響により，オンラインを 組み合わせた八イブリッド形式（図 1) で運営され，主催の 3か国に加え, 中国, イギリス, 米国, パキスタン, サウ ジアラビアから, 329 名の参加者でした. 発表論文数は合 計 223 件, そのうち, 口頭発表が 183 件, ポスタ一発表 40 件であり, 28 のレギュラ一セッション, 3 のポスター セッション, 及び 10 の特別セッションでプログラムが構 成されました，特別セッションでは，下記のとおり，システ ム数理と応用や, データサイエンスとAlをテーマにした合 計 46 件の発表がありました

WEIE Workshop

Emerging Technology

Machine Learning in Computer Vision

Mathematical Systems Science and its Applications

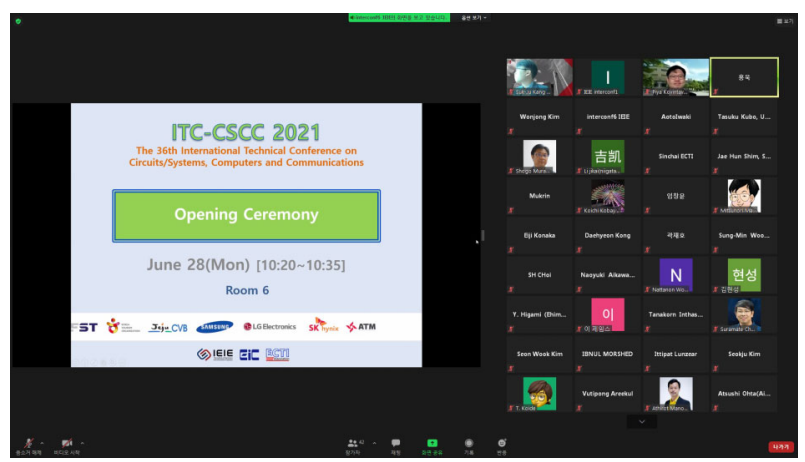

図 1 Zoom による Opening Ceremony

\author{
Advanced Data Storage Technology \\ Data Science and Artificial Intelligence \\ Recent Progress on Antennas and Microwave \\ Technologies \\ Semiconductor Standardization
}

全体企画の Plenary Talk として, 中央大学の牧野光則教 授による “Trends in Engineering Education and Quality Assurance in the 21 st Century" (図 2) と, タイのチェ ンマイ大学の Yuttana Kumsuwan 教授による“Common-Mode Voltage Mitigation by Modulation Techniques for Voltage Source Converters" 亡の, 2 件の発表 がありました．更に，東京農工大学の田中雄一准教授による "Sampling Signals on Networks:Graph Sampling Theory and Its Applications”を含む 3 件のチュートリア ル講演も行われました.

オンラインのオーラルセッションでは, 発表者は全員, 事 前にプレゼンテーションを動画収録し，運営本部に送信しま した. 当曰, 運営側で, その動画を再生し, その後, リアル タイムで発表者と聴講者が質疑応答する形式となりました. 一方, 現地会場でのオーラルセッションでは, 感染対策に万 全を期し，適切なソーシャルディスタンスをとり，運営され ました（図 3). 現地会場の様子はZ Zoom を用いて中継さ れ, オンラインで参加している聴講者は, 発表後, チャット 機能を使って質疑応答する形式となりました．オンラインの 参加者は，会議ホームページ上に掲示された各セッションの QR コードまたは URL（ハイパーリンク）から, Zoom へ アクセスしました。 ポスターセッションも, 飛沫対策のため マスク着用を徹底し, 活発な意見交換が行われました（図 4).

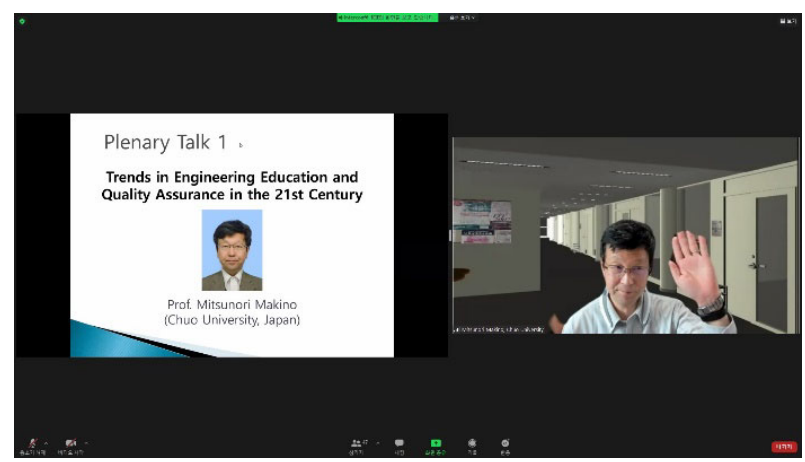

図 2 牧野教授による Plenary Talk 


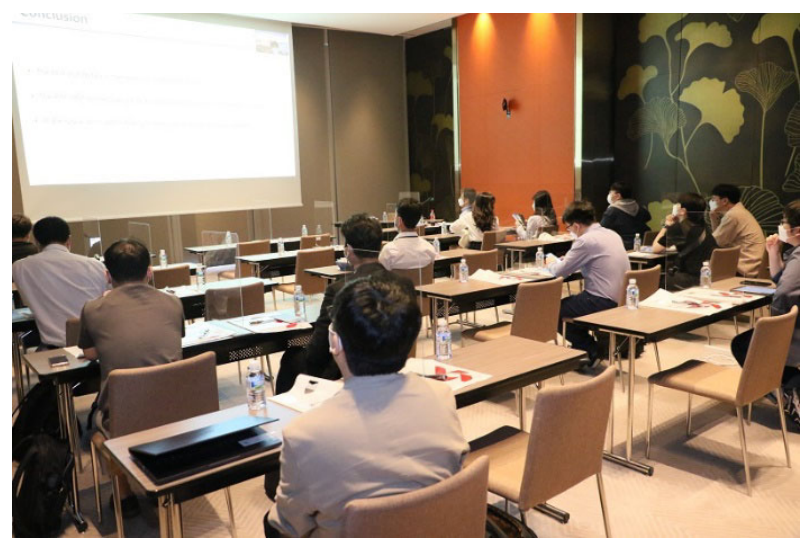

図３現地会場でのオーラルセッション

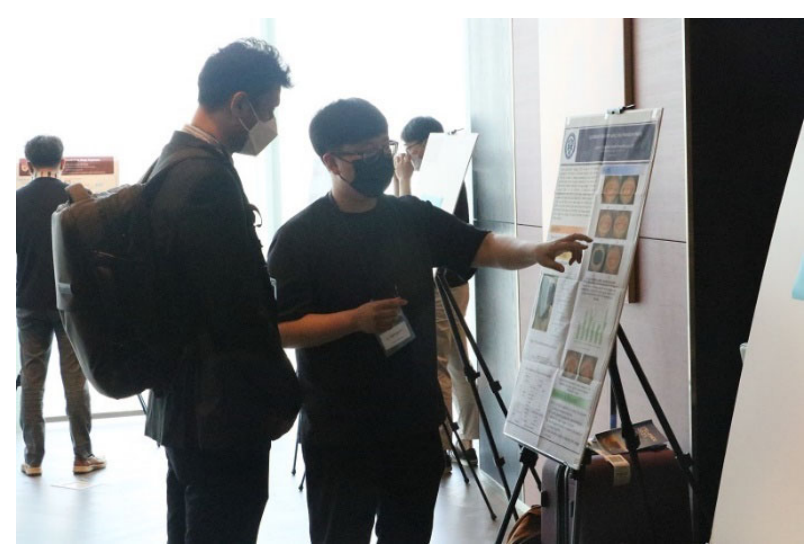

図 4 現地会場でのポスターセッション

新型コロナウイルス感染症の大流行によって, あらゆる研 究会や会議の形態を大きく変えざるを得ない状況の中, 新た な方策を模索し，中止や延期をすることなく，継続的に会議 を開催し, 成功させて頂いた全ての運営関係者に感謝したし ます. 全てのセッションにおいて, 活発な議論が交わされ, 国際的な研究の発展につながるシナジ一を生み出す貴重な機 会となりました.

次回 37 回は, 2022 年 7 月 5〜8 日に, タイのプー ケットで開催される予定です.

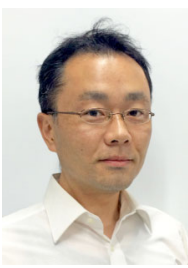

\section{篠宮紀彦 (正員 : 一般会員)}

1995 創価大·工・情報卒. 2001 同大学院博 士課程了. 2000 (株)富士通研究所ネットワーク システム研究所入社. 情報通信ネットワーク設計 と制御技術の研究に従事. 2005 創価大工学部専 任講師. 現在, 同大学理工学研究科教授, 情報シ ステム工学専攻長, 情報ネットワークセンター長. 2014 米国テキサス大学客員研究員. 博士 (工 学).2015 基礎・境界ソサイエティ貢献賞. ITC-CSCC2020 Technical Program Committee Chair. 